\title{
Faktor Risiko Penyebaran Escherichia coli Penghasil ESBL pada Ternak Ayam Komersial
}

\author{
Risk Factors for the Spread of ESBL-producing Escherichia coli in Commercial \\ Chicken Livestock
}

\section{Freshinta J. Wibisono}

Departement of Veterinary Public Health, Faculty of Veterinary Medicine, Wijaya Kusuma Surabaya University, Surabaya, Indonesia

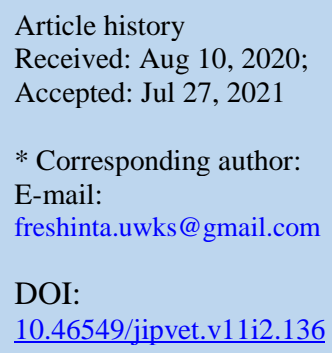

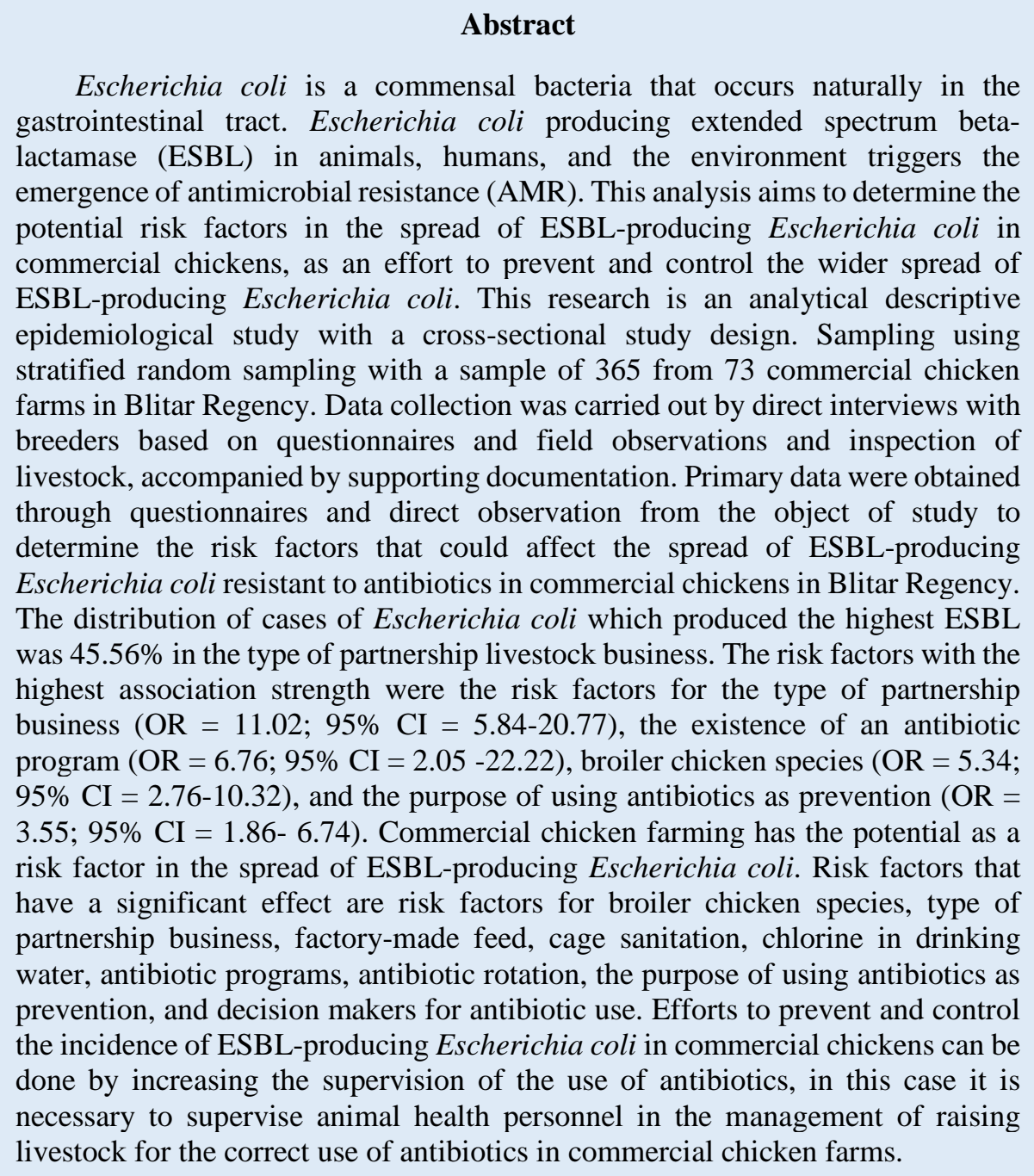

Escherichia coli is a commensal bacteria that occurs naturally in the gastrointestinal tract. Escherichia coli producing extended spectrum betalactamase (ESBL) in animals, humans, and the environment triggers the emergence of antimicrobial resistance (AMR). This analysis aims to determine the potential risk factors in the spread of ESBL-producing Escherichia coli in commercial chickens, as an effort to prevent and control the wider spread of ESBL-producing Escherichia coli. This research is an analytical descriptive epidemiological study with a cross-sectional study design. Sampling using stratified random sampling with a sample of 365 from 73 commercial chicken farms in Blitar Regency. Data collection was carried out by direct interviews with breeders based on questionnaires and field observations and inspection of livestock, accompanied by supporting documentation. Primary data were obtained through questionnaires and direct observation from the object of study to determine the risk factors that could affect the spread of ESBL-producing Escherichia coli resistant to antibiotics in commercial chickens in Blitar Regency. The distribution of cases of Escherichia coli which produced the highest ESBL was $45.56 \%$ in the type of partnership livestock business. The risk factors with the highest association strength were the risk factors for the type of partnership business $(\mathrm{OR}=11.02 ; 95 \% \mathrm{CI}=5.84-20.77)$, the existence of an antibiotic program $(\mathrm{OR}=6.76 ; 95 \% \mathrm{CI}=2.05-22.22)$, broiler chicken species $(\mathrm{OR}=5.34$; $95 \% \mathrm{CI}=2.76-10.32)$, and the purpose of using antibiotics as prevention $(\mathrm{OR}=$ 3.55 ; $95 \% \mathrm{CI}=1.86-6.74)$. Commercial chicken farming has the potential as a risk factor in the spread of ESBL-producing Escherichia coli. Risk factors that have a significant effect are risk factors for broiler chicken species, type of partnership business, factory-made feed, cage sanitation, chlorine in drinking water, antibiotic programs, antibiotic rotation, the purpose of using antibiotics as prevention, and decision makers for antibiotic use. Efforts to prevent and control the incidence of ESBL-producing Escherichia coli in commercial chickens can be done by increasing the supervision of the use of antibiotics, in this case it is necessary to supervise animal health personnel in the management of raising livestock for the correct use of antibiotics in commercial chicken farms.

Keywords: Commercial chicken; ESBL; Escherichia coli; Risk factors.

\section{Abstrak}

Escherichia coli merupakan bakteri komensal yang secara alami terdapat pada saluran cerna. Escherichia coli penghasil extended spectrum beta-lactamase (ESBL) pada hewan, manusia, dan lingkungan memicu munculnya antimicrobial resistance (AMR). Analisis ini bertujuan untuk mengetahui faktor risiko yang 
berpotensi dalam penyebaran bakteri Escherichia coli penghasil ESBL pada ternak ayam komersial, sebagai upaya pencegahan dan pengendalian penyebaran Escherichia coli penghasil ESBL yang lebih luas. Penelitian ini merupakan penelitian epidemiologi deskriptif analitik dengan desain cross-sectional study. Pengambilan sampel menggunakan stratified random sampling dengan pengambilan sampel sebanyak 365 ekor dari 73 peternakan ayam komersial di Kabupaten Blitar. Pengumpulan data dilakukan dengan wawancara secara langsung kepada peternak berdasarkan kuisoiner dan pengamatan di lapangan serta pemeriksaan terhadap ternak, dilengkapi dengan dokumentasi pendukung. Data primer diperoleh melalui kuisoiner dan pengamatan secara langsung dari objek penelitian untuk mengetahui faktor risiko yang dapat mempengaruhi penyebaran Escherichia coli penghasil ESBL yang resisten terhadap antibiotik pada ternak ayam komersial di Kabupaten Blitar. Distribusi kasus kejadian Escherichia coli penghasil ESBL tertinggi sebesar 45,56\% pada jenis usaha peternakan kemitraan. Faktor risiko dengan kekuatan asosiasi tertinggi pada faktor risiko jenis usaha kemitraan $(\mathrm{OR}=11,02 ; \mathrm{CI} 95 \%=5,84-20,77)$, adanya program pemberian antibiotik $(\mathrm{OR}=6,76$; $\mathrm{CI} 95 \%=2,05-22,22)$, spesies ayam broiler (OR $=5,34 ;$ CI $95 \%=2,76-10,32)$, dan tujuan penggunaan antibiotik sebagai pencegahan $(\mathrm{OR}=3,55$; CI 95\% = 1,86-6,74). Peternakan ayam komersial berpotensi sebagai faktor risiko dalam penyebaran kejadian Escherichia coli penghasil ESBL. Faktor risiko yang berpengaruh secara signifikan adalah faktor risiko spesies ayam broiler, jenis usaha kemitraan, pakan buatan pabrik, sanitasi kandang, klorin pada air minum, program antibiotik, rotasi antibiotik, tujuan penggunaan antibiotik sebagai pencegahan, dan pengambil keputusan penggunaan antibiotik. Upaya pencegahan dan pengendalian kejadian Escherichia coli penghasil ESBL pada ternak ayam komersial dapat dilakukan dengan meningkatkan pengawasan penggunaan antibiotik, sehubungan dengan hal ini diperlukan adanya pengawasan tenaga kesehatan hewan dalam manajemen pemeliharan ternak untuk penggunaan antibiotik secara benar di peternakan ayam komersial.

Kata kunci: Ayam komersial; ESBL; Escherichia coli; Faktor risiko

\section{PENDAHULUAN}

\section{Extended Spectrum Beta-Lactamase} (ESBL) berasal dari enzim beta-lactamase yang termutasi, sehingga menyebabkan terjadinya peningkatan aktivitas enzimatik beta-lactamase. Resistensi antibiotik terjadi pada spektrum yang lebih luas, yaitu golongan sefalosporin generasi ketiga (misalnya: ceftazidime, cefotaxime, dan ceftriaxone), dan monobactams (misalnya: aztreonam) tetapi tidak mempengaruhi cephamycins (misalnya: cefoxitin dan cefotetan) atau carbapenems (misalnya: meropenem dan imipenem) sehingga antibiotik menjadi tidak efektif (Paterson and Bonomo, 2005; (Kang et al., 2017); Hasibuan et al., 2018). Bakteri penghasil ESBL dapat menjadi resisten terhadap antibiotik golongan aminoglycoside, fluoroquinolon, tetracycline, chloramphenicol, dan sulfamethoxazole-trimethoprim (Brower $e t$ al., 2017); (Sudarwanto et al., 2017).

Extended Spectrum Beta-Lactamase paling banyak dihasilkan oleh kelompok Enterobacteriaceae, terutama Escherichia coli dan Klebsiella pneumoniae (Paterson and Bonomo, 2005; (Bramantoro et al., 2013). Escherichia coli merupakan bakteri yang terbagi menjadi dua kelompok utama yaitu strain komensal dan strain patogenik (Filho et al., 2015). Escherichia coli sebagai bakteri komensal yang bersifat multidrug resistance dapat menjadi masalah kesehatan karena mampu mentransfer gen resisten ke bakteri patogen lain dalam saluran cerna (Masruroh et al., 2016). Keberadaan bakteri penghasil ESBL pada manusia, hewan, dan lingkungan memicu munculnya resistensi antimikroba (Lukman et 
al., 2016); (Masruroh et al., 2016); Shoaib et al., 2016); (Sudarwanto et al., 2016); Falgenhauer et al., 2019); (Putra et al., 2019). Prevalensi Escherichia coli penghasil ESBL pada ternak di rumah potong hewan di Bogor dilaporkan sebesar 8,6\% (Sudarwanto et al, 2016), sedangkan di sekitar rumah potong hewan tersebut diketahui sebesar $14,3 \%$. Lingkungan berpotensi sebagai faktor penular kejadian Escherichia coli penghasil ESBL (Sudarwanto et al., 2017).

Peternakan ayam komersial merupakan salah satu sumber dari resistensi antibiotik. Antibiotik dalam peternakan ayam komersial digunakan sebagai upaya pengobatan dan sebagai pencegahan penyakit. Penggunaan antibiotik yang tidak terkontrol menyebabkan terjadinya resistensi antibiotik. Antibiotik yang sering digunakan pada peternakan ayam komersial adalah antibiotik golongan beta laktam yang bekerja menghambat dinding sel bakteri. Resistensi antibiotik beta laktam dapat terjadi pada bakteri Escherichia coli penghasil ESBL (Santos et al., 2013; (Hammerum et al., 2014). Penelitian sebelumnya telah banyak dilakukan, namun penelitian terbatas pada deteksi keberadaan Escherichia coli penghasil ESBL, sedangkan penelitian mengenai hubungan lingkungan dan faktor lain yang berisiko di Indonesia belum pernah diteliti, namun beberapa penelitian terdahulu pernah dilakukan di Tanzania dan India (Seni et al, 2016; Brower et al, 2017). Unggas merupakan salah satu reservoir penting dari agen bakterial (Suardana et al, 2014), sehingga potensi ayam komersial sebagai faktor penular kejadian Escherichia coli penghasil ESBL perlu diteliti lebih lanjut sebagai upaya pencegahan dan pengendalian penyebaran kejadian Escherichia coli penghasil ESBL yang lebih luas. Penelitian ini bertujuan untuk mengetahui faktor risiko yang berpotensi dalam penyebaran bakteri Escherichia coli penghasil ESBL pada ternak ayam komersial.

\section{MATERI DAN METODE}

Penelitian ini merupakan penelitian epidemiologi deskriptif analitik dengan desain cross-sectional study. Pengambilan sampel menggunakan stratified random sampling dengan pengambilan sampel sebanyak 5 ekor tiap peternakan ayam komersial di Kabupaten Blitar. Sampel sejumlah 365 ternak ayam dari 73 peternakan ayam komersial. Pengumpulan data dilakukan dengan wawancara secara langsung kepada peternak berdasarkan kuisoiner dan pengamatan di lapangan serta pemeriksaan terhadap ternak, dilengkapi dengan dokumentasi pendukung. Data primer diperoleh melalui kuisoiner dan pengamatan secara langsung dari objek penelitian untuk mengetahui faktor risiko yang dapat mempengaruhi kejadian Escherichia coli penghasil ESBL yang resisten terhadap antibiotik pada ternak ayam komersial di Kabupaten Blitar.

Variabel yang diamati meliputi peternak, pemeliharan ternak, dan manajemen pemberian antibiotik. Aspek peternak meliputi pendidikan peternak (pendidikan SD, SMP, SMA, dan Perguruan Tinggi), pendidikan peternak pada akhirnya terbagi menjadi dua kelompok yaitu pendidikan perguruan tinggi (PddkPT) dan pendidikan non perguruan tinggi (NonPddkPT). Pemeliharaan ternak ayam komersial meliputi jenis usaha peternakan (kemitraan dan mandiri), jenis ternak (broiler atau layer), pakan (pabrik dan racikan peternak), dukungan dokter hewan (ada dan tidak ada nya dukungan pada pemeliharan ternak ayam komersial), sanitasi kandang (bersih dan kurang bersih), klorin pada air minum (ada atau tidak), dan pengendapan air minum (ada perlakuan pengendapan atau tidak ada). Manajemen pemberian antibiotik meliputi ada nya program rencana pemberian antibiotik (ya atau tidak), ada nya rotasi jenis antibiotik yang diberikan (ya atau tidak), tujuan penggunaan antibiotik (pencegahan atau pengobatan), pemberian jenis antibiotik secara kombinasi (ya atau tidak), pengambilan keputusan penggunaan antibiotik (dokter hewan, teman, pengalaman sendiri, dan Technical Service), pengambilan keputusan penggunaan antibiotik pada akhir nya terbagi menjadi dua yaitu referensi dokter hewan (Refdrh) dan referensi selain dokter hewan (NonRefdrh). Variabel dependent pada analisis ini merupakan status kejadian resistensi bakteri 
Escherichia coli penghasil ESBL pada ternak ayam komersial di Kabupaten Blitar. Perhitungan asosiasi dianalisis menggunakan tabel 2x2 untuk mengetahui signifikansi Pearson's chi-square $\left(\chi^{2}\right)$, Yates' correction chi-square $\left(\chi^{2}\right)$ dan nilai probabilitas ( $p$-value). Pearson's chi square digunakan bila semua sel memiliki nilai lebih dari 5. Yates' correction chi square digunakan apabila terdapat sel dengan nilai kurang dari 5 dengan sampel lebih dari 15 (Martin et al., 1987); Sumiarto and Budiharta, 2018).

\section{HASIL DAN PEMBAHASAN}

\section{DESKRIPSI KASUS DAN FAKTOR RISIKO}

Kasus kejadian Escherichia coli penghasil ESBL pada ternak ayam komersial di Kabupaten Blitar merupakan kasus kejadian Escherichia coli penghasil ESBL yang mengalami resistensi terhadap beberapa antibiotik terutama golongan antibiotik beta lactam (cephalosphorin generasi ketiga dan monobactam) (Wibisono et al., 2020a); (Wibisono et al., 2020b); (Wibisono et al., 2020c); (Wibisono et al., 2020d);
(Witaningrum et al., 2020). Hasil penelitian menunjukkan bahwa pada ternak ayam komersial terdapat 94,5\% (345/365) positif terdapat Escherichia coli. Bakteri Escherichia coli ini merupakan bakteri komensal yang secara alami terdapat pada saluran cerna ayam (Conway and Cohen, 2015; (Filho et al., 2015); (Wibisono et al., 2020d). Keberadaan Escherichia coli penghasil ESBL (Tabel 1) tertinggi sebesar $45,56 \%$ pada jenis usaha peternakan kemitraan. Hasil penelitian ini menunjukkan tingginya kejadian bakteri Escherichia coli penghasil ESBL pada ayam komersial dengan jenis usaha kemitraan, dibandingkan pada ternak ayam komersial dengan jenis usaha mandiri (7,06\%). Distribusi kejadian tertinggi berikutnya adalah faktor adanya pemberian klorin pada air minum $(26,3 \%)$, penggunaan antibiotik sebagai pencegahan penyakit $(24,9)$, sanitasi kandang $(22,2 \%)$, adanya program pemberian antibiotik (21\%), dan tidak adanya rotasi penggunaan antibiotik pada ternak $(20,8 \%)$.

Tabel 1. Distribusi kasus kejadian Escherichia coli penghasil ESBL pada ternak ayam komersial di Kabupaten Blitar

\begin{tabular}{llr}
\hline \multicolumn{1}{c}{ Kriteria } & \multicolumn{1}{c}{ Variabel } & Hasil \\
\hline \multirow{2}{*}{ Jenis usaha } & 1. Mandiri & $7,06 \%(18 / 255)$ \\
& 2. Kemitraan & $45,56 \%(41 / 90)$ \\
Program antibiotik & 1. Ada & $21 \%(56 / 266)$ \\
Penggunaan antibiotik & 2. Tidak ada & $3,8 \%(3 / 79)$ \\
& 1. Pencegahan & $24,9 \%(45 / 181)$ \\
Rotasi antibiotik & 2. Pengobatan & $8,54 \%(14 / 164)$ \\
\multirow{2}{*}{ Sanitasi kandang } & 1. Ada & $11,6 \%(16 / 138)$ \\
& 2. Tidak ada & $20,8 \%(43 / 207)$ \\
Pengendapan air minum & 1. Bersih & $22,2 \%(34 / 153)$ \\
\multirow{2}{*}{ Klorin pada air minum } & 2. Kurang & $13 \%(25 / 192)$ \\
& 1. Ada & $13,8 \%(21 / 152)$ \\
& 2. Tidak ada & $19,7 \%(38 / 193)$ \\
\hline
\end{tabular}

Pada tingkat peternakan (Tabel 2), menunjukkan bahwa faktor pengambil keputusan penggunaan antibiotik $(80,8 \%)$, adanya program pemberian antibiotik $(76,7 \%)$, penggunaan pakan pabrik $(58,9 \%)$, dan penggunaan antibiotik sebagai pencegahan $(52,1 \%)$ menjadi faktor risiko tertinggi kejadian
Escherichia coli penghasil ESBL pada peternakan ayam komersial. Jenis usaha kemitraan mendominasi pada peternakan ayam broiler, sedangkan pada peternakan ayam layer didominasi oleh jenis usaha peternakan mandiri. Peternakan kemitraan memiliki rencana pemeliharaan dari inti kemitraan, sehingga 
pada peternakan kemitraan sebagian besar memiliki rencana program pemberian antibiotik. Hasil penelitian sesuai dengan penelitian sebelumnya yang menunjukkan $89 \%$ peternakan ayam broiler memiliki rencana penggunaan antibiotik dan terdapat $81 \%$ menggunakan antibiotik sebagai pencegahan
(Niasono, 2019). Pendekatan untuk menangani resistensi antibiotik berupa kebijakan seperti pengembangan dan penyebaran pedoman teknis, tetapi pedoman tanpa mempertimbangkan kompleksitas permasalahan praktik peternakan sehari hari sehingga diabaikan oleh peternak (Bellet, 2018)

Tabel 2. Distribusi faktor risiko kejadian Escherichia coli penghasil ESBL pada peternakan ayam komersial di Kabupaten Blitar

\begin{tabular}{lcc}
\hline \multicolumn{1}{c}{ Kriteria } & Kode variabel & Hasil \\
\hline Jenis Usaha & JUMitra & $24,7 \%(18 / 73)$ \\
\hline Pakan & PakPabrik & $58,9 \%(43 / 73)$ \\
\hline Dukungan drh & Dukudrh & $28,8 \%(21 / 73)$ \\
\hline Sanitasi Kandang & SaniKan & $43,8 \%(32 / 73)$ \\
\hline Klorin pada air minum & Tritklor & $47,9 \%(35 / 73)$ \\
\hline Pengendapan air minum & Tritendap & $45,2 \%(33 / 73)$ \\
\hline Program antibiotik & ProgAb & $76,7 \%(56 / 73)$ \\
\hline Rotasi antibiotik & RotasiAb & $41,1 \%(30 / 73)$ \\
\hline Penggunaan antibiotik & UseCegah & $52,1 \%(38 / 73)$ \\
\hline Antibiotik kombinasi & AbKombi & $49,3 \%(36 / 73)$ \\
\hline Pengambil keputusan penggunaan antibiotik & NonRefdrh & $80,8 \%(59 / 73)$ \\
\hline
\end{tabular}

\section{ASOSIASI FAKTOR RISIKO KEJADIAN}

ESCHERICHIA COLI PENGHASIL ESBL

Analisis bivariat faktor risiko kejadian Escherichia coli penghasil ESBL pada ternak ayam komersial di Kabupaten Blitar (Tabel 3) menunjukkan bahwa faktor risiko spesies ayam, jenis usaha, pakan, sanitasi kandang, klorin pada air minum, program antibiotik, rotasi antibiotik, tujuan penggunaan antibiotik, dan pengambil keputusan penggunaan antibiotik merupakan faktor risiko yang secara signifikan berhubungan dengan kejadian Escherichia coli penghasil ESBL pada ternak ayam komersial di Kabupaten Blitar. Kejadian Escherichia coli penghasil ESBL berdasarkan hasil observasi lapangan dan hasil pemeriksaan laboratorium menunjukkan bahwa kasus kejadian Escherichia coli penghasil ESBL dapat terjadi pada ternak ayam yang terlihat sehat. Pemberian antibiotik pada ayam sehat menyebabkan munculnya resistensi antibiotik sehingga pada saat ayam tersebut sakit menjadi kebal terhadap pengobatan antibiotik.
Keberadaan Escherichia coli penghasil ESBL pada ayam sehat, menunjukkan bahwa ayam merupakan reservoir potensial untuk Escherichia coli penghasil ESBL (Blanc et al., 2006); (Furtula et al., 2010); (Kemmett et al., 2014).

Analisis bivariat faktor risiko terhadap kejadian Escherichia coli penghasil ESBL pada ternak ayam komersial ditinjau dari aspek ternak meliputi ternak ayam broiler dan ternak ayam layer, dengan tingkat signifikansi $\mathrm{p}=$ $0,0000(\mathrm{p}<0,05)$ menggunakan Pearson's chisquare $\left(\chi^{2}\right)$ dengan nilai $\chi^{2}$ hitung 28,56 lebih besar daripada $\chi^{2}$ tabel $(3,84)$ maka Hipotesa awal $\left(\mathrm{H}_{0}\right)$ ditolak dan Hipotesa akhir $\left(\mathrm{H}_{1}\right)$ diterima.

Hasil signifikansi ini menunjukkan bahwa terdapat hubungan antara kejadian Escherichia coli penghasil ESBL dengan variabel spesies ternak (broiler maupun layer). Kekuatan dari hubungan tersebut dengan nilai $\mathrm{OR}=5,34$ menunjukkan bahwa kejadian Escherichia coli penghasil ESBL pada ternak ayam broiler 5 kali 
daripada ternak ayam layer.

Tabel 3 Analisis bivariat kejadian Escherichia coli penghasil ESBL ayam komersial

\begin{tabular}{|c|c|c|c|c|c|c|c|c|c|}
\hline \multirow{3}{*}{ Faktor risiko } & \multicolumn{4}{|c|}{ ESBL } & \multirow{3}{*}{ Total } & \multirow{3}{*}{$x^{2}$} & \multirow{3}{*}{ P-value } & \multirow{3}{*}{$\begin{array}{c}\text { OR } \\
95 \% \mathrm{CI}\end{array}$} & \multirow{3}{*}{$\begin{array}{c}\text { PR } \\
(95 \% \mathrm{CI})\end{array}$} \\
\hline & \multicolumn{2}{|c|}{ Positif } & \multicolumn{2}{|c|}{ Negatif } & & & & & \\
\hline & $\mathbf{n}$ & $\%$ & $\mathbf{n}$ & $\%$ & & & & & \\
\hline Spesies ayam & & & & & & \multirow{3}{*}{28,56} & \multirow{3}{*}{$0,0000 *$} & \multirow{3}{*}{$\begin{array}{r}5,34 \\
(2.76-10.32)\end{array}$} & \multirow{3}{*}{$\begin{array}{r}4.09 \\
(2.29 \\
7.29\end{array}$} \\
\hline Broiler & 46 & 28.75 & 114 & 71.25 & 160 & & & & \\
\hline Layer & 13 & 7.03 & 172 & 92.97 & 185 & & & & \\
\hline Pendidikan & & & & & & \multirow{3}{*}{1,64} & \multirow{3}{*}{0,2008} & \multirow{3}{*}{$\begin{array}{r}1.52 \\
(0.8-2.92)\end{array}$} & \multirow{3}{*}{$\begin{array}{r}1.43 \\
(0.82 \\
2.48)\end{array}$} \\
\hline NonPddkPT & 45 & 18.83 & 194 & 81.17 & 239 & & & & \\
\hline PddkPT & 14 & 13.21 & 92 & 86.79 & 106 & & & & \\
\hline Jenis Usaha & & & & & & \multirow{3}{*}{69,54} & \multirow{3}{*}{$0,0000 *$} & & \multirow{3}{*}{$\begin{array}{r}6.45 \\
(3.92 \\
10.63)\end{array}$} \\
\hline Mitra & 41 & 45.56 & 49 & 54.44 & 90 & & & 11,02 & \\
\hline Mandiri & 18 & 7.06 & 237 & 92.94 & 255 & & & $(5.84-20.77)$ & \\
\hline Pakan & & & & & & \multirow{3}{*}{8,73} & \multirow{3}{*}{$0,0031^{*}$} & & \multirow{3}{*}{$\begin{array}{r}2.27 \\
(1.28 \\
4.05\end{array}$} \\
\hline Pabrik & 46 & 21.9 & 164 & 78.1 & 210 & & & 2,63 & \\
\hline Racik & 13 & 9.63 & 122 & 90.37 & 135 & & & $(1.36-5.09)$ & \\
\hline Dukungan drh & & & & & & & & & \\
\hline Tidak ada & 45 & 17.86 & 207 & 82.14 & 252 & & 05204 & 1.23 & $\begin{array}{l}1.19 \\
0.68\end{array}$ \\
\hline Ada & 14 & 15.05 & 79 & 84.95 & 93 & 0,38 & 0,5394 & $(0.64-2.36)$ & $\begin{array}{r}(0.68- \\
2.06)\end{array}$ \\
\hline Sanitasi kandang & & & & & & & & & 171 \\
\hline Bersih & 34 & 22.22 & 119 & 77.78 & 153 & 500 & 00241 * & 1,91 & $1 . / 1$ \\
\hline Kurang & 25 & 13.02 & 167 & 86.98 & 192 & 5,09 & $0,0<41^{*}$ & $(1.08-3.37)$ & $2.73)$ \\
\hline Klorin pada air & & & & & & & & & \\
\hline Ada & 44 & 26.35 & 123 & 73.65 & 167 & & & 3,89 & 3.13 \\
\hline Tidak ada & 15 & 8.43 & 163 & 91.57 & 178 & 19,52 & $0,0000^{*}$ & $(2.07-7.31)$ & $(1.81-5.4)$ \\
\hline Pengendapan air & & & & & & & & & \\
\hline Tidak ada & 38 & 19.69 & 155 & 80.31 & 193 & 207 & 01503 & 1.53 & $\begin{array}{r}1.43 \\
087\end{array}$ \\
\hline Ada & 21 & 13.82 & 131 & 86.18 & 152 & $2,0 /$ & 0,1503 & $(0.86-2.74)$ & $\begin{array}{r}(0.8 /- \\
2.32)\end{array}$ \\
\hline Program antibiotik & & & & & & & & & 5.54 \\
\hline Ada & 56 & 21.05 & 210 & 78.95 & 266 & 11,6 & $0,0007 *$ & 6,76 & $\begin{array}{r}5.54 \\
(1.78\end{array}$ \\
\hline Tidak ada & 3 & 3.80 & 76 & 96.20 & 79 & & & $(2.05-22.22)$ & $\begin{array}{l}(1.78- \\
17.23)\end{array}$ \\
\hline Rotasi antibiotik & & & & & & & & & \\
\hline Tidak ada & 43 & 20.77 & 164 & 79.23 & 207 & 4,92 & $0,0265^{*}$ & 2 & 1.79 \\
\hline Ada & 16 & 11.59 & 122 & 88.41 & 138 & & & $(1.08-3.72)$ & $\begin{array}{l}(1.05- \\
3.05)\end{array}$ \\
\hline Penggunaan antibio & & & & & & & & & \\
\hline Pencegahan & 45 & 24.86 & 136 & 75.14 & 181 & 16,18 & $0,0001 *$ & 3,55 & 2.91 \\
\hline Pengobatan & 14 & 8.54 & 150 & 91.46 & 164 & & & $(1.86-6.74)$ & $\begin{array}{r}(1.66- \\
5.11)\end{array}$ \\
\hline $\begin{array}{l}\text { Antibiotik } \\
\text { kombinasi }\end{array}$ & & & & & & & & & \\
\hline Ya pernah & 34 & 20.24 & 134 & 79.76 & 168 & 227 & 01317 & 1.54 & 1.43 \\
\hline $\begin{array}{l}\text { Tidak } \\
\text { pernah }\end{array}$ & 25 & 14.12 & 152 & 85.88 & 177 & 2,27 & 0,1317 & $(0.88-2.72)$ & $(0.89-2.3)$ \\
\hline Pengambil keputusa & pengg & unaan a & tibioti & & & & & & \\
\hline NonRefdrh & 49 & 17.07 & 238 & 82.93 & 287 & 0 & 0,9752 & 1 & 1 \\
\hline Refdrh & 10 & 17.24 & 48 & 82.76 & 58 & & & $(0.47-2.09)$ & $\begin{array}{r}(0.53- \\
1.84)\end{array}$ \\
\hline
\end{tabular}

*Significant if $\mathrm{P}<0.05(\alpha=0.05)$ 
Hasil analisis bivariat ini sesuai dengan hasil penelitian yang menunjukkan bahwa kejadian Escherichia coli penghasil ESBL di Kabupaten Blitar pada ayam broiler sebesar $28,75 \%$ atau berisiko 4 kali lebih berisiko daripada ternak ayam layer yang memiliki kejadian Escherichia coli penghasil ESBL sebesar 7,03\%. Hasil penelitian ini berhubungan dengan peternakan broiler umumnya rentan terhadap penyakit. Ternak ayam broiler secara umum lebih rentan dari ternak ayam layer, sehingga peternak cenderung memberikan program pemberian antibiotik sebagai pencegahan penyakit infeksi pada manajemen ternak ayam broiler (Etikaningrum and Iwantoro, 2017; (Rahman et al., 2017).

Aspek manajemen pemeliharaan peternakan meliputi jenis usaha peternakan (mandiri maupun kemitraan). Hasil signifikansi menunjukkan bahwa terdapat hubungan antara kejadian Escherichia coli penghasil ESBL pada ternak ayam komersial dengan variabel jenis usaha peternakan ayam (mandiri maupun kemitraan), sebesar OR $=11,02$ yang menunjukkan bahwa kejadian Escherichia coli penghasil ESBL pada usaha ternak kemitraan 11 kali daripada usaha ternak mandiri. Hasil analisis ini sesuai dengan hasil penelitian yang menunjukkan bahwa kejadian Escherichia coli penghasil ESBL pada usaha kemitraan sebasar $45,56 \%$ atau sebesar 6 kali lebih berisiko daripada jenis usaha mandiri yang menunjukkan kejadian Escherichia coli penghasil ESBL sebesar 7,06\%. Peternakan kemitraan merupakan peternakan yang bergantung pada kontrak kerja antara peternak dengan inti kemitraan. Inti kemitraan telah memberikan suatu paket manajemen pemeliharaan berupa pakan, obat-obatan, dan jadwal program pengobatan. Peternak melaksanakan program pengobatan yang telah disusun oleh inti kemitraan tanpa melihat agen penyebab suatu penyakit. Jenis usaha kemitraan lebih tinggi penggunaan antibiotik dengan alasan terapi pencegahan agar peternak dan inti kemitraan tidak mengalami kerugian karena serangan penyakit infeksi (Wibisono et al., 2020d).

Variabel pakan ternak meliputi pakan buatan pabrik dan pakan racikan peternak memberikan hasil yang signifikan berhubungan. Kekuatan dari asosiasi tersebut dapat dilihat dari nilai $O R$ dengan nilai $O R=2,63$ menunjukkan bahwa kejadian Escherichia coli penghasil ESBL pada ternak dengan pakan buatan pabrik 3 kali daripada pakan racikan sendiri. Aspek penggunaan antibiotik ditinjau dari ada tidaknya program pemberian antibiotik pada ternak ayam menunjukkan hasil signifikansi terdapat hubungan antara kejadian Escherichia coli penghasil ESBL dengan variabel adanya program pemberian antibiotik. Kekuatan hubungan dengan nilai $\mathrm{OR}=6,76$ menunjukkan bahwa kejadian Escherichia coli penghasil ESBL pada ternak dengan program pemberian antibiotik 7 kali daripada ternak yang tidak menggunakan program pemberian antibiotik. Hasil analisis bivariat ini sesuai dengan hasil penelitian yang menunjukkan kejadian Escherichia coli penghasil ESBL pada ternak yang memiliki program pemberian antibiotik sebesar $21 \%$ atau 7 kali lebih tinggi daripada ternak yang tidak menggunakan program pemberian antibiotik $(3,8 \%)$. Asosiasi antara kejadian Escherichia coli penghasil ESBL dengan variabel program pemberian antibiotik berkorelasi dengan variabel tujuan pemberian antibiotik sebagai pencegah atau pengobatan penyakit. Hasil signifikansi menunjukkan bahwa terdapat hubungan antara kejadian Escherichia coli penghasil ESBL dengan variabel tujuan pemberian antibiotik. Kekuatan asosiasi dengan nilai $\mathrm{OR}=3,55$ menunjukkan bahwa kejadian Escherichia coli penghasil ESBL pada ternak dengan pemberian antibiotik sebagai pencegahan penyakit $3 \mathrm{kali}$ daripada pemberian antibiotik sebagai pengobatan. Hasil analisis ini sesuai dengan hasil penelitian yang menunjukkan bahwa kejadian Escherichia coli penghasil ESBL pada ternak dengan pemberian antibiotik sebagai pencegahan penyakit sebesar $24,9 \%$ atau 3 kali lebih berisiko dibandingkan dengan penggunaan antibiotik sebagai pengobatan penyakit sebesar $8,54 \%$. Perunggasan secara umum menggunakan antibiotik untuk meningkatkan performa produksi melalui perbaikan konversi pakan, meningkatkan pertumbuhan dan mencegah penyakit terutama 
kontrol infeksi saluran cerna (Mehdi et al., 2018). Penggunaan antibiotik yang tinggi dikarenakan persepsi peternak menyatakan antibiotik tersebut tidak memiliki efek samping (Memish et al., 2004).

\section{KESIMPULAN}

Peternakan ayam komersial berpotensi sebagai faktor risiko dalam penyebaran kejadian Escherichia coli penghasil ESBL. Faktor risiko yang berpengaruh secara signifikan adalah faktor risiko spesies ayam, jenis usaha, pakan, sanitasi kandang, klorin pada air minum, program antibiotik, rotasi antibiotik, tujuan penggunaan antibiotik, dan pengambil keputusan penggunaan antibiotik. Faktor risiko spesies ayam broiler 5 kali lebih besar dari kejadian pada ayam layer. Jenis usaha kemitraan lebih berisiko 11 kali lebih besar daripada kejadian pada jenis usaha peternakan yang dikelola secara mandiri oleh peternak. Jenis pakan buatan pabrik 3 kali lebih besar pada pakan racikan sendiri. Program pemberian antibiotik 7 kali lebih besar daripada peternakan yang tidak terdapat program antibiotik, dan tujuan penggunaan antibiotik sebagai pencegahan penyakit menimbulkan kejadian 3 kali lebih besar daripada peternakan yang menggunakan antibiotik sebagai pengobatan pada saat kejadian penyakit. Upaya pencegahan dan pengendalian kejadian Escherichia coli penghasil ESBL pada ternak ayam komersial dapat dilakukan dengan meningkatkan pengawasan penggunaan antibiotik.

\section{DAFTAR PUSTAKA}

Bellet C. 2018. Change it or perish? Drug resistance and the dynamics of livestock farm practices. Journal of Rural Studies. 63:57-64. doi:10.1016/j.jrurstud.2018.08.016.

Blanc V, Mesa R, Saco M, Lavilla S, Prats G, Miró E, Navarro F, Cortés P and Llagostera M. 2006. ESBL- and plasmidic class $C \beta$ lactamase-producing $E$. coli strains isolated from poultry, pig and rabbit farms. Veterinary Microbiology. 118:299-304. doi:10.1016/j.vetmic.2006.08.002.
Bramantoro, Purwati dan Hamidah. 2013. The prevalence of Extended Spectrum BetaLactamase (ESBL) in third generation cephalosporin usage among sepsis patients in the Department of Internal Medicine RSUD DR. Soetomo Surabaya. Folia Medica Indonesiana. 49:244-251.

Brower CH, Mandal S, Hayer S, Sran M, Zehra A, Patel SJ, Kaur R, Chatterjee L, Mishra S, Das BR, Singh P, Singh R, Gill JPS and Laxminarayan R. 2017. The prevalence of Extended-Spectrum Beta Lactamaseproducing multidrug-resistant Escherichia coli in poultry chickens and variation according to farming practices in Punjab, India. Environmental Health Perspectives. 125:1-10. doi:10.1289/EHP292.

Conway T and Cohen PS. 2015. Commensal and Pathogenic Escherichia coli Metabolism in the Gut. Microbiol Spectr. 347:882-886. doi:10.1128/microbiolspec. MBP-0006-2014.

Etikaningrum dan Iwantoro S. 2017. Kajian Residu Antibiotika pada Produk Ternak Unggas di Indonesia. Jurnal Ilmu Produksi dan Teknologi Hasil Peternakan. 05:29-33.

Falgenhauer L, Imirzalioglu C, Oppong K, Akenten CW, Hogan B, Krumkamp R, Poppert S, Levermann V, Schwengers O, Sarpong N, Owusu-Dabo E, May J and Eibach D. 2019. Detection and characterization of ESBL-producing Escherichia coli from humans and poultry in Ghana. Frontiers in Microbiology. 10:18. doi:10.3389/fmicb.2018.03358.

Filho HCK, Brito KCT, Cavalli LS and Brito BG. 2015. Avian Pathogenic Escherichia coli (APEC) - an update on the control. The battle against microbial pathogens: Basic science, technological advances and educational programs. 598-618.

Furtula V, Farrell EG, Diarrassouba F, Rempel H, Pritchard J and Diarra MS. 2010. Veterinary pharmaceuticals and antibiotic resistance of Escherichia coli isolates in poultry litter from commercial farms and controlled feeding trials. Poultry Science. 89:180-188. doi:10.3382/ps.2009-00198.

Hammerum AM, Larsen J, Andersen VD, Lester CH, Skytte TSS, Hansen F, Olsen 
SS, Mordhorst H, Skov RL, Aarestrup FM and Agers $\varnothing$ Y. 2014. Characterization of extended-spectrum $\beta$-lactamase (ESBL)producing Escherichia coli obtained from Danish pigs, pig farmers and their families from farms with high or no consumption of third- or fourth-generation cephalosporins. Journal of Antimicrobial Chemotherapy. 69:2650-2657. doi:10.1093/jac/dku180.

Hasibuan M, Suryanto D dan Kusumawati RL. 2018. Phenotypic and molecular detection of BLACTX-M gene Extended-Spectrum Beta-Lactamases in Escherichia coli and Klebsiella pneumoniae of North Sumatera isolates. IOP Conference Series: Earth and Environmental Science. 130. doi:10.1088/1755-1315/130/1/012032.

Kang D, Sinuraya RK, Rostinawati T dan Abdulah R. 2017. Gene blaCTX-M Mutation as Risk Factor of Antibiotic Resistance. Jurnal Farmasi Klini Indonesia. 6:135-152. doi:10.15416/ijcp.2017.6.2.135.

Kemmett K, Williams NJ, Chaloner G, Humphrey S, Wigley P and Humphrey T. 2014. The contribution of systemic Escherichia coli infection to the early mortalities of commercial broiler chickens. Avian Pathology. 43:37-42. doi:10.1080/03079457.2013.866213.

Lukman DW, Sudarwanto MB, Purnawarman T, Latif H, Pisestyani H, Sukmawinata E dan Akineden Ö. 2016. CTX-M-1 and CTX-M-55 producing Escherichia coli isolated from broiler feces in Poultry Slaughterhouse, Bogor, West Java Province. Global Advanced Research Journal of Medicine and Medical Sciences (ISSN: 2315-5159). 5:287-291.

Martin SW, Meek AH and Willeberg P. 1987. Veterinary Epidemiology Principles and Methods. First edit. Iowa State University Press, Ames, United States of America.

Masruroh CA, Sudarwanto MB dan Latif $\mathrm{H}$. 2016. Tingkat kejadian Escherichia coli penghasil Extended Spectrum BetaLactamase yang diisolasi dari feses broiler di Kota Bogor. Jurnal Sain Veteriner. 34:42-49.

Mehdi Y, Létourneau-Montminy MP, Lou
Gaucher M, Chorfi Y, Suresh G, Rouissi T, Brar SK, Côté C, Ramirez AA and S. Godbout. 2018. Use of antibiotics in broiler production: Global impacts and alternatives. Animal Nutrition. 4:170-178. doi:10.1016/j.aninu.2018.03.002.

Memish ZA, Balkhy HH, Shibl AM, Barrozo CP and Gray GC. 2004. Streptococcus pneumoniae in Saudi Arabia: Antibiotic resistance and serotypes of recent clinical isolates. International Journal of Antimicrobial Agents. 23:32-38. doi:10.1016/j.ijantimicag.2003.05.008.

Niasono AB. 2019. Resistensi antibiotik terhadap e. coli yang diisolasi dari peternakan ayam broiler di kabupaten subang. Institut Pertanian Bogor.

Paterson DL and Bonomo RA. 2005. Extended Spectrum Beta-Lactamases: a Clinical Update. Clinical Microbiology Reviews. 18:657-686. doi:10.1128/CMR.18.4.657.

Putra ARS, Effendi MH, Koesdarto S and Tyasningsih W. 2019. Molecular identification of Extended Spectrum BetaLactamase (ESBL) producing Escherichia coli isolated from dairy cows in East Java Province, Indonesia. Indian Veterinary Journal. 96:26-30.

Rahman MA, Rahman MM, Moonmoon M, Alam KJ and Islam MZ. 2017. Prevalence of common diseases of broiler and layer at Gazipur district in Bangladesh. Asian Journal of Medical and Biological Research. 3:290-293. doi:10.3329/ajmbr.v3i2.33582.

Santos LL dos, Moura RA, Aguilar-Ramires P, De Castro AP and Lincopan N. 2013. Current status of extended-spectrum $\beta$ lactamase (ESBL) -producing Enterobacteriaceae in animals. Microbial pathogens and strategies for combating them: Science, technology and education. 1600-07.

Seni J, Falgenhauer L, Simeo N, Mirambo MM, Imirzalioglu C, Matee M, Rweyemamu M, Chakraborty T and Mshana SE. 2016. Multiple ESBL-producing Escherichia coli sequence types carrying quinolone and aminoglycoside resistance genes circulating in companion and domestic 
farm animals in Mwanza, Tanzania, harbor commonly occurring plasmids. Frontiers in Microbiology. 7:1-8. doi:10.3389/fmicb.2016.00142.

Shoaib M, Kamboh AA, Sajid A, Mughal GA, Leghari RA, Malhi KK, Bughio SUD, Ali A, Alam S, Khan S and Ali S. 2016. Prevalence of Extended Spectrum BetaLactamase Producing Enterobacteriaceae in Commercial Broilers and Backyard Chickens. Advances in Animal and Veterinary Sciences. 4:209-214. doi:http://dx.doi.org/10.14737/journal.aav s/2016/4.4.209.214.

Suardana IW, Utama IH, Putriningsih PAS dan Rudyanto MD. 2014. Uji Kepekaan Antibiotika Isolat Escherichia coli O157: H7 asal Feses Ayam. Buletin Veteriner Udayana. 6:19-27.

Sudarwanto MB, Lukman DW, Latif $\mathrm{H}$, Pisestyani H, Sukmawinata E, Akineden Ö and Usleber E. 2016. CTX-M producing Escherichia coli isolated from cattle feces in Bogor slaughterhouse, Indonesia. Asian Pacific Journal of Tropical Biomedicine. 6:605-608. doi:10.1016/j.apjtb.2016.05.001.

Sudarwanto MB, Lukman DW, Latif $H$, Pisestyani H, Sukmawinata E, Purnawarman T. 2017. Multidrug resistance Extended Spectrum BetaLactamase and AmpC producing Escherichia coli isolated from the environment of Bogor Slaughterhouse, Indonesia. Asian Pacific Journal of Tropical Biomedicine. 7:708-711. doi:10.1016/j.apjtb.2017.07.012.

Sumiarto B dan Budiharta S. 2018. Epidemiologi Veteriner Analitik. Gadjah Mada University Press, Yogyakarta.

Wibisono FJ, Sumiarto B, Untari T, Effendi $\mathrm{MH}$, Permatasari DA and Witaningrum
AM. 2020a. Short Communication: The presence of extended-spectrum betalactamase (ESBL) producing Escherichia coli on layer chicken farms in Blitar Area, Indonesia. Biodiversitas, Journal of Biological Diversity. 21:2667-2671. doi:DOI: 10.13057/biodiv/d210638.

Wibisono FJ, Sumiarto B, Untari T, Effendi $\mathrm{MH}$, Permatasari DA and Witaningrum AM. 2020b. Short communication: Pattern of antibiotic resistance on extendedspectrum beta-lactamases genes producing escherichia coli on laying hens in Blitar, Indonesia. Biodiversitas, Journal of Biological Diversity. 21:4631-4635. doi:10.13057/biodiv/d211022.

Wibisono FJ, Sumiarto B, Untari T, Effendi $\mathrm{MH}$, Permatasari DA and Witaningrum AM. 2020c. Resistance Profile of Extended Spectrum Beta Lactamase-Producing Escherichia coli Bacteria using Vitek ${ }^{\circledR} 2$ Compact Method. Bulletin of Animal Science. 44:48-53.

Wibisono FJ, Sumiarto B, Untari T, Effendi $\mathrm{MH}$, Permatasari DA and Witaningrum AM. 2020d. Prevalence and Risk Factors Analysis of Multidrug Resistance of Escherichia coli Bacteria in Commercial Chicken, Blitar District. Jurnal Ilmu Peternakan dan Veteriner Tropis (Journal of Tropical Animal and Veterinary Science). 10:15. doi:10.46549/jipvet.v10i1.74.

Witaningrum AM, Wibisono FJ, Permatasari DA, Tyaningsih $\mathrm{W}$, Effendi $\mathrm{MH}$ and Kurniawan F. 2020. Potential hazards of antibiotics resistance on escherichia coli isolated from cloacal swab in several layer poultry farms, Blitar, Indonesia. Indian Journal of Public Health Research and Development. 11:2389-2395. 